Clark, J. B. (1953). J. gen. Microbiol. 8, 45-49.

\title{
The Effects of Chemicals on the Recombination Rate in Bacterium coli
}

\author{
BY J. BENNETT CLARK \\ Department of Plant Sciences, University of Oklahoma, \\ Norman, Oklahoma, U.S.A.
}

SUMMARY: The rate of prototroph formation as a result of gene recombination in multiple mutants of Bacterium coli, strain $\mathrm{K}-12$, is altered by addition of various chemicals to the nutrient substrate in which the recombining strains are grown. There is some correlation between the appearance of filamentous forms of the organism and the rate of gene recombination.

The recombination of genetic factors in Bacterium coli, strain K-12, and their segregation into prototroph recombinants as reported by Lederberg (1947), has been confirmed by several workers. Nelson (1951) has applied statistical methods to show this phenomenon to be a true recombination. Haas, Wyss \& Stone (1948) found that ultraviolet irradiation of the recombining strains produced a marked increase in the number of prototrophs formed, and they reported a parallel increase in the number of filamentous 'large forms' of cells in the cultures. A similar increase in the rate of formation of prototrophs was reported by Clark, Haas, Stone \& Wyss (1950) when the recombining strains were cultured together in substrates that had been treated with hydrogen peroxide or irradiated with ultraviolet light. When the strains were grown together in the presence of sublethal concentrations of sodium azide, an increase was also found. These cultural conditions also caused an increase in the number of filaments, but because of experimental procedures it was impossible to obtain any direct correlation between the rate of recombination and the incidence of appearance of the abnormal forms of Bact. coli.

In view of the possible significance of the Bact. coli filaments in genetic recombination, it was decided to test the effects of various chemical agents on the recombination rate. These chemicals were chosen on the basis of previous observations which had revealed that various degrees of pleomorphism resulted when they were incorporated into media on which Bact.coli was grown.

\section{EXPERIMENTAL}

The recombining mutants of Bact. coli used were strains Y-53 and 58-161 (kindly furnished by Dr J. Lederberg). Strain Y-53 requires threonine, leucine, and thiamine for growth, and strain 58-161 requires biotin and methionine. Nutrient agar was utilized as a complete medium for determining total viable cell counts, and asparagine glucose mineral salt agar (Lederberg, 1947) was used as a minimal medium for determining prototroph formation.

The soluble chemicals used were made in concentrated solutions and sterilized by filtration through a UF fritted glass filter. Appropriate amounts 
of the sterile chemical were aseptically added to $50 \mathrm{ml}$. samples of nutrient broth to give the desired final concentrations. Compounds which were only slightly soluble in water were added directly to the nutrient broth in the desired concentration and autoclaved with the substrate.

The treated nutrient broth samples were inoculated with $0.1 \mathrm{ml}$. of a log phase culture of each of the recombining strains. After $24 \mathrm{hr}$. incubation, the resulting cultures were washed twice by centrifugation, resuspended in $50 \mathrm{ml}$. of saline, and plated in appropriate dilutions in nutrient agar for total count and in the minimal agar for prototroph count.

The treated media were tested for the presence of possible factors of selection by comparing the rates of growth of each of the deficient strains and the prototrophs in nutrient broth and in nutrient broth in the presence of the chemical. In no case was evidence found that any change in the rate of recombination was caused by this factor of selection.

Each experiment was repeated several times, and in every case the same proportional increase or decrease in the rate of prototroph formation was observed. Thus, although the recombination rate in some cases is not vastly different from that of the control, it is believed that all results are significant.

\section{RESULTS}

Microscopic examination of all cultures grown in the presence of the chemicals tested revealed varying degrees of pleomorphism, including in many cases the long filamentous cell forms. However, it was impossible to obtain any direct correlation between the rate of prototroph formation and the incidence of filamentous forms because of the time lag incubation necessary to insure prototroph formation. Table 1 shows the effects of small concentrations of norleucine on the recombination rate. The variation in the prototroph formation with different concentrations of the amino-acid follows the same pattern as found for direct ultraviolet irradiation (Haas et al. 1948), indirect ultraviolet irradiation, hydrogen peroxide treatment, and sodium azide treatment (Clark et al. 1950).

$\begin{array}{cccc}\begin{array}{c}\text { Table 1. Effect of norleucine on the recombination rate in Bact. coli } \\ \text { Concentration } \\ (\mu \mathrm{g} . / \mathrm{ml} .)\end{array} & \text { Total count } \times 10^{6} & \text { Prototrophs } & \text { Prototrophs } / 10^{7} \text { cells } \\ 0 & 299 & 410 & 13 \\ 100 & 326 & 180 & 6 \\ 300 & 277 & 820 & 30 \\ 500 & 412 & 950 & 22\end{array}$

The presence of sulphanilamide or sulphanilic acid in the substrate during prototroph formation does not cause any apparent increase in prototrophs, as shown in Table 2. However, as the concentration was increased, the incidence of recombination was steadily decreased. This decreased rate was observed with other compounds and may be of equal significance with the increased rates; also it could be due to a suppression of prototrophs by the parent cells (Grigg, 1952). 
The antibiotics, penicillin and streptomycin, were also used in sublethal concentrations to determine their effect on the recombination rate. Penicillin was used in concentrations of 20 and 40 units $/ \mathrm{ml}$. and streptomycin was used in a concentration of $1 \mathrm{unit} / \mathrm{ml}$. In the concentrations used, cell clumping made it impossible to obtain good duplicate experiments. However, the data obtained indicated a marked decrease in the rate of prototroph formation. Some clumping was noticed in the presence of other chemicals, but this was negligible, and it is not believed that the cell aggregates were involved in gene recombination since no correlation was found between the degree of clumping and the subsequent rate of recombination. Such a possibility cannot be entirely eliminated, however. It has been suggested by Squires \& Fuller (1952) that within limits, cell clumps should be regarded as individual cells.

Table 2. Effect of sulphanilamide and sulphanilic acid on the recombination rate in Bact. coli

$\begin{array}{lcccc}\text { Chemical } & \begin{array}{c}\text { Concentration } \\ (\mu \mathrm{g} . / \mathrm{ml} .)\end{array} & \text { Total count } \times 10^{8} & \text { Prototrophs } & \text { Prototrophs } / 10^{7} \text { cell } \\ \text { None (control) } & - & 420 & 500 & 12 \\ \text { Sulphanilamide } & 100 & \mathbf{3 5 5} & 500 & 14 \\ \text { Sulphanilamide } & 500 & 371 & 300 & 8 \\ \text { Sulphanilamide } & 1000 & 223 & 110 & 5 \\ \text { Sulphanilic acid } & 1000 & 370 & 120 & 3\end{array}$

Table 3. Effect of various chemicals on the recombination rate in Bact. coli

\begin{tabular}{|c|c|c|c|c|}
\hline Chemical & $\begin{array}{c}\text { Concentration } \\
(\%)\end{array}$ & $\begin{array}{c}\text { Total } \\
\text { count } \times 10^{6}\end{array}$ & Prototrophs & $\begin{array}{c}\text { Prototrophs } / 10^{7} \\
\text { cells }\end{array}$ \\
\hline None (control) & - & 342 & 360 & 11 \\
\hline Methylcholanthrene & Sat. & 333 & 435 & 13 \\
\hline Acenaphthene & Sat. & $\mathbf{2 8 8}$ & 245 & 9 \\
\hline $1,2,5,6$-dibenzanthracene & Sat. & 323 & 260 & 8 \\
\hline Colchicine & $0 \cdot 5$ & 358 & 90 & $\mathbf{3}$ \\
\hline Colchicine & $1 \cdot 0$ & 312 & 390 & 12 \\
\hline Ascorbic acid & $0 \cdot 25$ & 219 & $\mathbf{2 5 5}$ & 12 \\
\hline Indole-3-acetic acid & 0.001 & 361 & 210 & 6 \\
\hline Potassium nitrate & $5 \cdot 0$ & 23 & 148 & 64 \\
\hline Magnesium sulphate & $5 \cdot 0$ & 260 & 540 & 21 \\
\hline
\end{tabular}

A group of compounds were chosen because of their carcinogenic activity or their effects on nuclear activity in cells. Of these compounds, only colchicine had any appreciable effect and then only in one concentration used as indicated in Table 3. All of these compounds caused pleomorphic cell formation, but in no instance were any filamentous forms observed. The effect of the colchicine was confirmed on repeated experiments.

Other compounds tested were ascorbic acid, which had no effect, and indole-3-acetic acid, which lowered the rate of prototroph formation. High concentrations of potassium nitrate and magnesium sulphate gave a pronounced increase in rate.

The possibility of induced back-mutation in the recombining strains was 
eliminated by testing the strains individually for back-mutation in the presence of each of the chemicals used. In no case was any evidence of back-mutation obtained.

\section{DISCUSSION}

In view of the lack of knowledge of the mechanisms involved in genetic recombination in Bact. coli, it is difficult to evaluate the possible reasons for the alteration of the rate of prototroph formation when cultural conditions are varied. Only generalized concepts can be used as an explanation of such results. The possibility of a life cycle in bacteria has been discussed in detail by Dienes \& Weinberger (1951). The correlation between filamentous forms and recombination rate as reported by Haas et al. (1948) would fit well into the concept of a life cycle. The conditions under which the rate of prototroph formation is altered also change the incidence of appearance of filamentous forms, although no direct correlation has been obtained. It is possible that the rate of formation of possible sexual forms will vary depending on the conditions of the substrate.

A second possibility is that recombination involves a transfer of diffusible material across the cell membrane of the living cell. This is particularly plausible in view of the effects that high osmotic pressure has on the recombination rate. Such a mechanisn could be considered as an in vivo transformation, although a transformation as reported in Bact. coli by Boivin (1947) and by Wyss (1950) has not been demonstrated.

Hayes (1952) suggested that a bacteriophage might be involved in the transference of genetic properties in prototroph formation in Bact. coli. Weigle \& Delbrück (1951) have found that the K-12 strain harbours a phage which can be liberated by small doses of ultraviolet light. It is possible that the rate of release of this phage from the host cell could be altered by the chemical composition of the substrate. If the phage were involved in the gene recombination, this could explain the altered rates.

The recent work of Grigg (1952) must also be considered in the interpretation of data on recombination rate. He demonstrated a suppression of the appearance of mutant forms in the presence of large numbers of the parent population. It is possible that the incidence of the appearance of prototrophs may be dependent on the number of auxotrophic parent cells present in the mixed culture. In these experiments the number of viable cells at the time of plating was essentially equal in all cases except in those experiments concerning potassium nitrate. Thus it would be expected that any effects of the parent cells on the recombinants would also be essentially equal. However, it is impossible to predict what differential changes might occur as a result of the population pressures exerted over the $24 \mathrm{hr}$. incubation period. These possible complex factors of selection are now being investigated.

The author wishes to acknowledge the helpful suggestions and criticisms of this work by Dr Orville Wyss and Dr Wilson S. Stone at the University of Texas. 


\section{REFERENCES}

Borvin, A. (1947). Directed mutation in colon bacilli, by an inducing principle of desoxyribonucleic nature: its meaning for the general biochemistry of heredity. Cold Spr. Harb. Sym. quant. Biol. 12, 7.

Clark, J. B., HaAs, F., Stone, W. S. \& Wyss, O. (1950). The stimulation of gene recombination in Escherichia coli. J. Bact. 59, 375.

Dienes, L. \& Weinberger, H. J. (1951). The L forms of bacteria. Bact. Rev. 15, 245.

GrigG, G. W. (1952). Back mutation assay method in micro-organisms. Nature, Lond. 169, 98.

HaAs, F., Wyss, O. \& Stone, W. S. (1948). The effect of irradiation on recombination in Escherichia coli. Proc. nat. Acad. Sci., Wash. 34, 229.

HAYES, W. (1952). Recombination in Bact. coli $\mathrm{K} 12$ : unidirectional transfer of genetic material. Nature, Lond. 169, 118.

LEDERBERG, J. (1947). Gene recombination and linked segregation in Escherichia coli. Genetics, 32, 505.

Nelson, T. C. (1951). Kinetics of genetic recombination in Escherichia coli. Genetics, 36, 162.

Squires, W. C. \& Fuller, J. E. (1952). On the relationship of bacterial clumps to plate counts. Bact. Proc. p. 34.

Weigle, J. J. \& Derbrück, M. (1951). Mutual exclusion between an infecting phage and a carried phage. J. Bact. 62, 301.

Wyss, O. (1950). Bacterial resistance. Ann. N.Y. Acad. Sci. 53, 183.

(Received 21 May 1952) 